\title{
Design, Sizing and Implementation of a PV System for Powering a Living Room
}

\author{
Marwa Sayed Salem Basyoni ${ }^{1}$, Mona Sayed Salem Basyoni ${ }^{2}$, Kawther Al-Dhlan ${ }^{3}$ \\ ${ }^{1,2,3}$ Computer Science and Engineering College, ${ }^{1}$ University of Hail, Kingdom of Saudi Arabia \\ ${ }^{1}$ Modern Science and Arts University (MSA), Cairo, Egypt
}

\begin{abstract}
This paper aims to design size and implement a Photo Voltaic system (PV system) for powering a living room. The required load to be powered by the PV system is completely determined. A comparison between using normal and power saving loads is carried out. The power saving loads is chosen to reduce the overall cost of the required system. The proposed $P V$ system for powering the predetermined load is introduced. Each part of the system is designed and sized based on the load requirement. Finally, the practical implementation for the overall PV system for powering the required load is done. The implemented system works in an efficient way.
\end{abstract}

Keywords - Design, Sizing, Implementation, PV system.

\section{INTRODUCTION}

Recent researches focus on renewable energy recourses [1,2]. This is because the already existed energy sources, which mainly based on fuel, are going to run out [3, 4]. There are many types of renewable energy resources [1]. Solar energy is considered the most attractive renewable energy source. This is because it is mainly the source of all other energy sources. In addition it gives higher output power comparing with other renewable energy sources [5, 6]. The main objective of this paper is to use the Photo - Voltaic (PV) system as a renewable energy source instead of the existed energy sources which based on fuel for powering a certain load. The system has to be implemented efficiently to satisfy the load requirements. Thus the load has to be firstly determined. A comparison between normal load and power saving loads is carried out. The power saving loads is chosen to reduce the overall cost of the PV system. The design sizing for each part of the required PV system is presented based on the load requirements. Each part of the PV system is tested practically to check its functionality. Finally the overall PV system is implemented to power the required load.

\section{NORMAL LOADS AND POWER SAVING LOADS}

The main objective of using the PV system is to power home utilities in the case of light goes out. In emergency cases, it is not required to power the whole home utility. The selected load as a case study in this paper is to power a living room, lamps for both of the kitchen and the bathroom. The utilities which are selected to be powered by the PV system are a LCD TV, Laptops with internet, fan and power saving Lamps. Also, the lighting of both the bathroom and the kitchen are taking into consideration. Table (1) shows some appliances and loads with its power consumption [7]. From table 1, it is obvious that the power saving loads consume less power comparing with the normal loads. For example, the laptop consumes $1 \mathrm{KWH}$ when it is used for 60 hours but the desktop computer with monitor consumes $8 \mathrm{KWH}$. Also the LCD TV uses low power comparing to the standard TV. Thus, the power saving loads is used to reduce the overall cost of the PV system.

The daily energy consumption for a certain load, Wattage * Hours used per day, is calculated as follow [8]:

$$
\frac{(\text { Wattage } * \text { Hours used per day })}{1000}=\text { Daily kilo watt hour }
$$

The contribution in this paper is to use smart (power saving loads) loads instead of normal loads. Normal loads consume much more power comparing to the power saving loads. Thus by using the power saving loads, the required power reduces. As a result, the overall cost of the required PV system reduces. The system design and sizing are based on calculations. 
TABLE 1

SOME APPLIANCES AND LOADS WITH ITS POWER CONSUMPTION

\begin{tabular}{|c|c|c|c|c|}
\hline APPLIANCE & HOURS IN USE & KWH USED & MONTHS USED & ANNUAL KWH \\
\hline $\begin{array}{c}\text { Computer - Desktop with } \\
\text { Monitor }\end{array}$ & 90 & 8 & 12 & 96 \\
\hline Computer - Laptop & 60 & 1 & 12 & 12 \\
\hline Fan - Bath & 15 & 1 & 6 & 72 \\
\hline $\begin{array}{c}\text { Fan - Ceiling (does not incl. } \\
\text { lights) }\end{array}$ & 150 & 12 & 3 & 33 \\
\hline Fan - Table / Box / Floor & 71 & 11 & 12 & 120 \\
\hline $\begin{array}{c}\text { Lighting - Incandescent, 100 } \\
\text { watts }\end{array}$ & 100 & 10 & 12 & 216 \\
\hline $\begin{array}{c}\text { Lighting - CFL, 25 watts } \\
\text { Television - 27 inch, LCD flat } \\
\text { screen }\end{array}$ & 100 & 1 & 12 & 216 \\
\hline $\begin{array}{c}\text { Television - 15-27 inch, } \\
\text { standard }\end{array}$ & 150 & 18 & 12 & \\
\hline
\end{tabular}

Table (2) shows the difference between using power saving loads and normal loads required for a living room, the used case study. Such loads are assumed to be used for 10 hours per day. The power calculations based on equation (1).

TABLE 2

DIFFERENCE BETWEEN POWER SAVING \&NORMAL LOADS IN LIVING ROOM

\begin{tabular}{|c|c|c|c|c|}
\hline Used Load & \multicolumn{2}{|c|}{ Power saving loads power } & \multicolumn{2}{c|}{ Normal Load power } \\
\cline { 2 - 5 } (Assume each used 10 hours per day) & Watt & Watt-hour/day & Watt & Watt-hour/day \\
\hline Lighting & 4 & 40 & 36 & 360 \\
\hline TV 19” & 22 & 220 & 80 & 800 \\
\hline Fan & 45 & 450 & 60 & 600 \\
\hline Total & $71 \mathrm{~W}$ & $710 \mathrm{~W} . \mathrm{H} / \mathrm{D}$ & $176 \mathrm{~W}$ & $1760 \mathrm{~W} . \mathrm{H} / \mathrm{D}$ \\
\hline
\end{tabular}

From table 2, it is obvious that the normal loads require power ten times more than the required power for the power saving loads. Thus the overall cost of the PV system using the power saving loads is predicted to be reduced.

\section{PV SYSTEM DESIGN AND SIZING}

In this section the design of each part of the PV system is presented. Figure 1 shows the required PV system to be implemented for powering any domestic use [9]. In this paper, it is required to power a living room with the lighting of both the kitchen and bathroom.

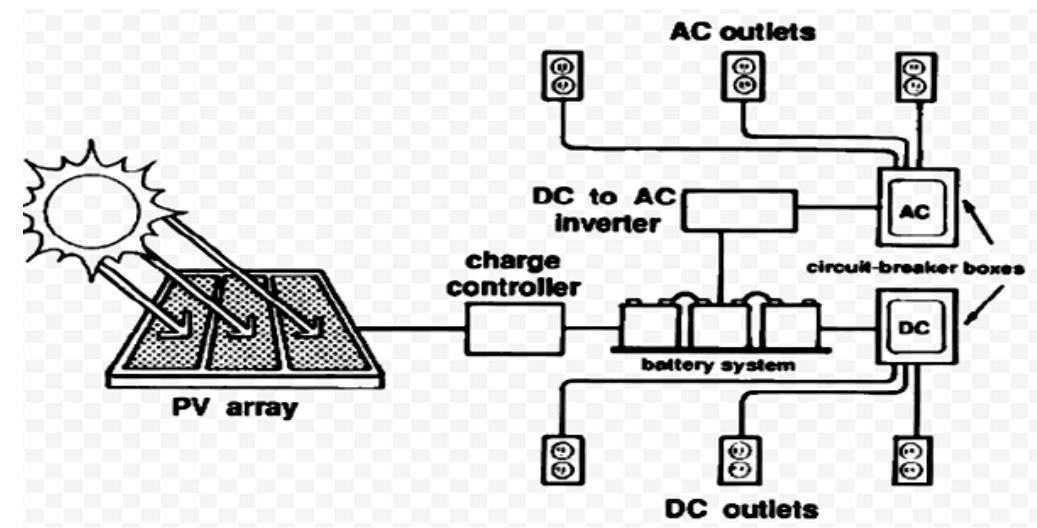

FIGURE 1: THE FUNCTIONAL BLOCK DIAGRAM OF THE REQUIRED PV SYSTEM FOR POWERING BOTH AC AND DC LOADS 


\subsection{Loads consumption demand}

Loads consumption must be determined to be able to determine the specification of PV system components. The loads consumption is determined for the living room utilities. PV system has high power dissipation through its components. Thus a safety margin has to be taking into consideration is the system design [9]. The following calculations show a comparison between the load consumption using normal loads and power saving. This consumption based on powering the main requirements of the living room and the lighting for both the bathroom and the kitchen, one TV, one fan, three light bulbs. The system is designed to power the required loads for 5 hours per day.

\subsubsection{Load Consumption using Normal loads:}

One 70W LED television 19" used 5 hours per day $70 * 5=350 \mathrm{Wh}$

One $75 \mathrm{~W}$ fan used 5 hours per day: $75 * 5=375 \mathrm{Wh}$

Three-100W light Bulb used 5 hours per day: $3 * 100 * 5=1500 \mathrm{Wh}=1.5 \mathrm{KWh}$

One 100W Desktop with Monitor used 5 hours per day: 100*5=500Wh

TOTAL DAILY LOAD $2725 \mathrm{Wh} /$ day

\subsubsection{Load Consumption Power Saving Loads:}

One $22 \mathrm{~W}$ LED television 19 " used 5 hours per day $22 * 5=110 \mathrm{Wh}$

One $20 \mathrm{~W}$ fan used 5 hours per day: $20 * 5=100 \mathrm{Wh}$

Four $-4 \mathrm{~W}$ light Bulb used 5 hours per day: $4 * 4 * 5=80 \mathrm{Wh}$

One 60W Lab top used 5 hours per day: $60 * 5=300 \mathrm{Wh}$

\subsubsection{TOTAL DAILY LOAD 590Wh /day}

From this calculation, it is obvious that the normal loads consume much more power than the power saving loads. These calculations confirm that using power saving loads reduces the overall cost of the PV system. As it reduces the overall required daily power consumption, it requires less number of solar panel. Also, the requirements of the system components reduce.

Thus the total power consumed by the required loads is $590 \mathrm{Wh} /$ day. The system is design to deliver $650 \mathrm{Wh} /$ day as a safety margin for the design.

\subsection{Panels' estimation}

In this paper, the living room is to be implemented using power saving loads. From loads calculations, the power from the solar panel must be calculated using the following rule [10]:

$$
\frac{\text { Daily energy loads consumption }}{\text { hours of usable sunlight during day }}=\text { power of panels power of panels }
$$

The number of solar panels used varies based on the load requirements. To size the panels, to determine the required number of panels to be used with its required power, the total peak watt produced must be calculated. The peak watt $\left(\mathrm{W}_{\mathrm{p}}\right)$ [11] produced depends on size of the PV module and climate of site location. In KSA, it enjoys sunshine all the year. In system design, six hours of sunshine all over the day is assumed. Thus, each watt peak $\left(\mathrm{W}_{\mathrm{p}}\right)$ of solar panel would therefore deliver $6 \mathrm{Wh} /$ day. Thus the required power from the solar panel is calculated using equation 2.

The daily energy loads consumption is $650 \mathrm{Wh}$. The hours of usable sunlight during day is assumed to be 6 hours. Thus the required output power from the solar panel is $109 \mathrm{~W}$. Thus a $120 \mathrm{~W}$ solar panel is used as a safety margin for the design. 


\subsection{Charge controller Design and Sizing}

The charge controller is used in PV system for controlling charging and discharging operation of battery from solar panels. The main objective of charge controller is to regulate the charge to the batteries and preventing any overcharging. When the battery becomes full the charge controller disconnects it from panels [9].

The input power from panels to charge controller is calculating using equation 3, assuming the worst case efficiency of charge controller equals to $85 \%$ :

$$
\text { Input Power }(\text { from panels })=\frac{\text { Output power }}{\text { Efficiency }(\eta)}
$$

Thus the input power to the controller is $141 \mathrm{~W}$.

The charge controller rating is calculated by dividing its input power by the maximum voltage of the used solar panel. The maximum voltage of the solar panel is $18 \mathrm{~V}$ [12]. Thus the rating of the charge controller to be used for the PV system is 7.88A. It is designed to be $10 \mathrm{~A}, 12 \mathrm{~V}$ as a safety margin for the design.

\subsection{Batteries}

The battery is used to store the generated energy from the solar panel and deliver it to the load [9]. There are many types of the battery [13]. The dry battery is the type which is used in this paper. It is most common used because it has a long lifetime and it is good in maintenance.

The capacity of battery is measure in ampere-hours (Ah). It is calculated by using equation 4[13]:

$$
\text { Capacity }(\mathrm{Ah})=\frac{\text { Daily energy loads consumption }(\mathrm{Wh})}{\max \text { panel volt }(\mathrm{V})}
$$

Assume that the battery has efficiency of $85 \%$. To save its lifetime, it is assumed to discharging to $60 \%$ from its value. So the capacity of the required battery to be used in this system is calculated using equation 5 .

$$
\text { Capacity }(\mathrm{Ah})=\frac{\text { Total } \text { Watt }- \text { hours per day used by appliances }}{(0.85 \times 0.6 \times \text { nominal battery voltage })}
$$

Assuming the worst case of using $85 \%$ battery efficiency and $60 \%$ depth of discharge and $12 \mathrm{~V}$ battery, as the total watt hours per day is $650 \mathrm{~W}$, thus the battery storage energy is calculated using equation 5 . It is found to be $106 \mathrm{Ah}$. A $120 \mathrm{Ah}$ battery is used for design safety.

\subsection{The Inverter}

The inverter is used to convert direct current (DC) produced from panel, to alternative current (AC) that needs to power the AC loads in home [9]. The efficiency of inverter is in the range of $90 \%$ to $95 \%$ because the power loss occurs in the conversion process. The efficiency of inverter can be calculated by using equation 6 [13].

$$
\text { Efficiency }(\eta)=\frac{\text { Output power (to loads) }}{\text { Input power (come from charge controller) }}
$$

Assuming worst case inverter efficiency to be $90 \%$, so the input power to the inverter coming from the charge controller is calculated using equation 7 .

$$
\text { Input Power ( from charge controller) }=\frac{\text { Output power (to loads) }}{\text { Efficiency }(\eta)} \frac{\text { Output power (to loads) }}{\text { Efficiency }(\eta)}
$$

The inverter power must be sufficient to handle the total amount of Watts that required by the system. The inverter size should be $25-30 \%$ greater than the required watt for the load [13]. To size the inverter, the total power of the used load must be calculated. It is around $118 \mathrm{~W}$. Thus a $150 \mathrm{~W}$ inverter is required for design safety margin.

Thus the requirement of the $\mathrm{PV}$ system required to power a $650 \mathrm{Wh} / \mathrm{day}$ for a living room with the lighting of a kitchen and a bathroom are: 
One solar panel with $120 \mathrm{~W}$, Charge controller rated at $10 \mathrm{~A}$ at $12 \mathrm{~V}$, a battery with capacity of $120 \mathrm{Ah}$ and $12 \mathrm{~V}$, Inverter with size greater than $150 \mathrm{~W}$

Figure 2 shows the practical components which are used for implementing the PV system
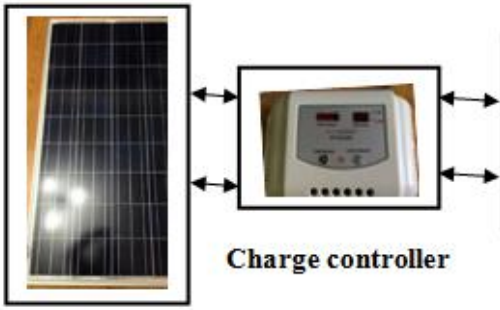

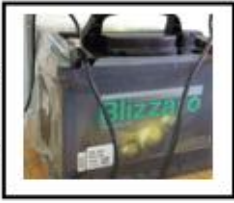

Battery

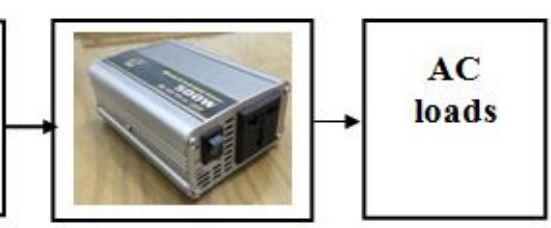

Inverter

Panels

\section{FIGURE 2: THE PRACTICAL COMPONENTS OF THE IMPLEMENTED PV SYSTEM}

The PV is implemented and tested. It is working in an efficient way. It powers the loads when the light goes out for 5 continuous hours. There are supporting videos for practical implementation and testing for the PV system.

\section{CONCLUSION}

A PV system for powering a living room with the lighting of both the kitchen and the bathroom is implemented. The power saving loads is used instead of the normal loads. It consumes less power. Thus it reduces the overall cost of the PV system. The required load is completely determined. Each part of the PV system is designed and sized. The implemented system is tested. It works effectively. It powers the required load for five continuous hours when light goes out.

\section{REFERENCES}

[1] Faruk Yildiz, "Potential Ambient Energy-Harvesting Sources and Techniques", The Journal of Technology Studies, 2009

[2] S. Roundy, P. K. Wright, and J. M. Rabaey, "Energy Scavenging for Wireless Sensor Networks", 1st ed. Boston, Massachusetts: Kluwer Academic Publishers, 2003

[3] V. A. Boichenko, E. Greenbaum, and M. Seibert, Photoconversion of Solar Energy, molecular to global photosynthesis. Imperial College Press London: 2004; p 397-452

[4] S. Bahatyrova, R. N. Frese, C. A. Siebert, J. D. Olsen, K. O. van der Werf, R. van Grondelle, R. A. Niederman, P. A. Bullough, C. Otto, and C. N. Hunter, Nature 430, (7003), 1058-1062 (2004).

[5] Nathan S. Lewis and George Crabtree, Argonne Arthur Nozik, NU Paul Alivisatos, "Basic Research Needs for Solar Energy Utilization", Report of the Basic Energy Sciences Workshop on Solar Energy Utilization , UC-Berkeley, 2005

[6] Z. Fan, J. C. Ho, "Self-assembly of One-dimensional Nanomaterials for Cost-effective Photovoltaics", International Journal of Nanoparticles, 4, 164 (2011)

[7] "Electrical Appliance Typical Energy Consumption Table", http://www.chabotspace.org/assets/BillsClimateLab/Electrical\%20Appliance\%20Typical\%20Energy\%20Consumption\%20Table.pdf

[8] "How to calculate domestic power consumption?" https://dmohankumar.wordpress.com/2012/08/12/how-to-calculate-domestic-power-consumption-fact-file-24/

[9] Vince Lombardi, ed. “A Practical Guide to Solar Power System Design for Homeowners”, Version 08.08.12

[10] http://www.solartechnology.co.uk/support-centre/calculating-your-solar-requirments

[11] Hemakshi Bhoye, Gaurang Sharma, “An Analysis of One MW Photovoltaic Solar Power Plant Design”, International Journal of Advanced Research in Electrical, Electronics and Instrumentation Engineering, Vol. 3, Issue 1, January 2014

[12] http://www.centsys.co.za/upload/CENTSYS\%20Documentation/0_07_B_0133\%20120W\%20Solar\%20Panel\%20Specifications\%20s heet-29062015-NG.pdf

[13] B. Westover, "Difference between Dry Cells and Wet Cells". http://www.ehow.com/about_6360799_difference-wet-cell-dry-cell_.html\#ixzz2rAxAHcmk.

[14] H. Wade, “Solar PV Design Implementation O\& M”, March 31- April 11, 2008 